\title{
Pengembangan Panduan Bimbingan Dan Konseling Untuk Mengembangkan Kecerdasan Sosial Siswa
}

\author{
Maryam Rahim \\ Psikologi Pendidikan dan Bimbingan, Universitas Negeri Gorontalo, Indonesia \\ Email:maryamrahim63@gmail.com \\ Meiske puluhulawa \\ Psikologi Pendidikan dan Bimbingan, Universitas Negeri Gorontalo, Indonesia \\ Email: puluhulawameiske@gmail.com
}

(Diterima: 09-Mei-2018; direvisi: 08-Agustus-2018; dipublikasikan: 29-Desember-2018)

\begin{abstract}
This study aims to produce a guide to improve teacher competency in guidance and counseling in developing social intelligence of seventh grade junior high school students, which consists of: (1) service syllabus and plan for implementing guidance and counseling services, (2) teacher guidance, (3) material services, and (4) evaluation guidelines. The procedure for developing a 5-step guide is: (1) analyzing the product to be developed, (2) developing the initial product, (3) expert validation and revision, (4) small-scale field testing and product revision, and (5) trial large scale field and final product. Based on the results of expert validation data analysis, small group test data and large group tests, as well as product revisions based on the results of data analysis that has been obtained, guidance and counseling service guides can be produced that have criteria for developing social intelligence of seventh grade junior high school students. This guide consists of (1) service syllabus and plan for implementing guidance and counseling services, (2) teacher guidance, (3) service material, and (4) evaluation guidelines. It is expected that the guidance and counseling teachers can use this guide in carrying out guidance and counseling services for the development of students' social intelligence, especially seventh grade junior high school students.
\end{abstract}

Keyword: Guidance and counseling; Social Intelligence

\begin{abstract}
Abstrak: Penelitian ini bertujuan menghasilkan panduan untuk meningkatkan kompetensi guru bimbingan dan konseling dalam mengembangkan kecerdasan sosial siswa SMP kelas VII, yang terdiri dari: (1) silabus layanan dan rencana pelaksanaan layanan bimbingan dan konseling,(2) panduan guru, (3) materi layanan, dan (4) panduan evaluasi. Prosedur pengembangan panduan 5 langkah utama yakni: (1) melakukan analisis produk yang akan dikembangkan, (2) mengembangkan produk awal, (3) validasi ahli dan revisi, (4) uji lapangan skala kecil dan revisi produk, dan (5) uji coba lapangan skala besar dan produk akhir. Berdasarkan hasil analisis data validasi ahli, data uji kelompok kecil dan uji kelompok besar, serta revisi-revisi produk berdasarkan hasil analisis data yang telah diperoleh, dapat dihasilkan panduan layanan bimbingan dan konseling yang memiliki kriteria untuk mengembangkan kecerdasan sosial siswa SMP kelas VII. Panduan ini terdiri dari (1) silabus layanan dan rencana pelaksanaan layanan bimbingan dan konseling, (2) panduan guru, (3) materi layanan, dan (4) panduan evaluasi. Diharapkan para guru bimbingan dan konseling dapat menggunakan panduan ini dalam melaksanakan layanan bimbingan dan konseling untuk pengembangan kecerdasan sosial siswa khususnya siswa SMP kelas VII.
\end{abstract}

Keywords: Bimbingan dan Konseling; Kecerdasan Sosial

Copyright $\odot 2018$ Universitas Negeri Makassar. This is an open access article under the CC BY-NCND license (http://creativecommons.org/licenses/by-nc-nd/4.0/). 


\section{8 | Jurnal Psikologi Pendidikan \& Konseling Vol. 4 No. 2 Desember 2018}

\section{PENDAHULUAN}

Pendidikan dilaksanakan untuk membantu individu siswa memperoleh perkembangan yang optimal dalam berbagai aspek, yang meliputi aspek kognitif, afektif dan psikomotor. Melalui pendidikan ketiga aspek tersebut dikembangkan secara utuh dalam rangka menciptakan siswa yang tidak saja berkompoten dalam aspek pengetahuan, tetapi juga dalam aspek keterampilan dan sikap. Namun realita dalam kehidupan keseharian, tampaknya ketiga aspek tersebut kurang berkembang secara simultan, yang ditunjukan oleh berbagai perilaku siswa yang cenderung menyimpang dari normanorma sosial dan moral. Fenomena perilaku bullying, tawuran, dan tindakan kriminal yang sering dilakukan oleh siswa sekolah menengah pertama menjadi indikasi perlunya pengembangan aspek afektif khususnya aspek kecerdasan sosial siswa secara berkelanjutan. Dari data survei, sebanyak 84 persen anak usia 12 tahun hingga 17 tahun pernah menjadi korban bullying (viva, 2017)

Di samping itu, Komisi Perlindungan Anak Indonesia (KPAI) mencatat kasus tawura di Indonesia meningkat 1,1 persen sepanjang 2018. Pada tahun lalu, angka kasus tawuran hanya 12,9 persen, tapi tahun ini (tahun 2018) menjadi 14 persen (metro, 2018)

Layanan bimbingan dan konseling sebagai bagian integral dari pendidikan di sekolah memiliki peranan penting dalam mengembangkan kecerdasan sosial siswa, dalam penelitian ini difokuskan pada siswa kelas VII. Penetapan kelas VII didasarkan pada pertimbangan bahwa para siswa tersebut sedang dalam masa awal di tingkat sekolah menengah pertama setelah mereka meninggalkan tahap sekolah dasar. Sebagai upaya membantu guru bimbingan dan konseling melaksanakan layanan untuk pengembangan kecerdasan sosial siswa secara sistematis dan berkelanjutan maka dilakukan penelitian pengembangan yang menghasilkan panduan bimbingan dan konseling kecerdasan sosial siswa sekolah menengah pertama. Panduan ini diharapkan akan menjadi pedoman yang jelas bagi guru bimbingan dan konseling dalam menciptakan siswa sekolah menengah pertama yang memiliki kecerdasan sosial yang tinggi.Permasalahan dalam penelitian ini adalah: bagaimanakah panduan layanan bimbingan dan konseling untuk mengembangkan kecerdasan sosial siswa sekolah menengah pertama kelas VII? Dengan demikian pengembangan panduan ini bertujuan untuk menghasilkan panduan layanan bimbingan dan konseling dalam mengembangkan kecerdasan sosial siswa SMP Kelas VII.

Siswa sekolah menengah pertama merupakan individu yang sedang dalam proses perkembangan dalam berbagai aspek fisik maupun aspek psikis. Proses perkembangan itu memerlukan perhatian, pengawasan, pengarahan, serta bimbingan dari orang-orang di sekitarnya, yakni orang tua, guru, tokoh masyarakat, dan orang dewasa lainnya. Kecerdasan sosial merupakan salah satu aspek perkembangan yang membutuhkan perhatian, pengawasan, pengarahan, serta bimbingan, agar siswa sebagai individu memiliki kecerdasan sosial yang sangat berperan penting dalam kehidupan siswa, baik kehidupan belajar, kehidupan pribadi, kehidupan sosial, maupun kehidupan karir.

Berkenan dengan kehidupan belajar, setiap siswa diharapkan mencapai hasil belajar atau prestasi belajar yang optimal. Pencapaian hasil belajar ataupun prestasi belajar tersebut turut dipengaruhi oleh kecerdasan sosial siswa. Hasil-hasil penelitian telah menemukan adanya korelasi antara hasil belajar yang dicapai siswa dengan kecerdasan sosial, seperti penelitian yang telah dilakukan oleh Baggiyam dan Pankajan (2017); Asma, Tasleema dan Gani (2015); Manullang (2015); dan Wulandari (2014), yang menemukan adanya korelasi positif antara kecerdasan sosial dengan pretasi akademik. Rahim, dkk $(2017,4)$ menjelaskan bahwa berbagai aktivitas belajar kelompok yang dilakukan siswa mengharuskan setiap siswa memiliki kecerdasan sosial. Dalam belajar kelompok para siswa saling berinteraksi dengan sesama siswa, yang tidak lepas dari persoalan kemampuan berinteraksi sosial, interaksi sosial tentu akan memberikan pengaruh yang baik (Bakhtiar, 2015). Siswa harus mampu mengendalikan emosi, mampu memahami pikiran dan perasaan orang lain, mampu mendengarkan secara terbuka penyampaian orang lain, mampu menyelaraskan diri dengan orang, serta peduli terhadap kebutuhan orang lain. Semakin siswa memiliki kemampuankemampuan tersebut, semakin banyak manfaat yang diperolehnya dalam aktivitas belajar kelompok, antara lain perolehan hasil belajar yang lebih baik.

Kehidupan siswa sebagai makhluk sosial membutuhkan kecerdasan sosial dari setiap siswa. Berbagai hasil kajian telah menjelaskan pentingnya kecerdasan sosial dalam kehidupan manusia pada umumnya. Beheshtifar dan 
Roasaei (2012) memberikan kesimpulan berdasarkan kajiannya terhadap pendapat beberapa ahli, seperti Marlowe (1986), dan Dong, et al (2008) yang mengatakan bahwa "individuals who are socially intelligent appear to experience a rich, meaningful life, as opposed to to truncated affective experiences. Furthermore, aspects of social intelligence have been found to be associated with enhanced social problem-solving abilities, experienced leadership, and positive interpersonal experience. Selanjutnya Beheshtifar dan Roasaei menunjukkan studi yang telah dilakukan oleh Zaccaro, et al (2003) menyimpulkan juga adanya korelasi antara kecerdasan sosial dengan kepemimpinan.

Kecerdasan sosial dibutuhkan siswa dalam kehidupannya sebagai pribadi. Beberapa hasil penelitian telah menemukan adanya korelasi dan kontribusi kecerdasan sosial terhadap aktivitas dan perilaku siswa serta individu pada umumnya. Shekarey, et al (2013) melalui penelitiannya menyimpulkan "that there was a negative and significant relationship between the student's social intelligence and their aggressive behaviors. In other words, the students having high social intelligence are calm and they indicate less aggressive behaviors. As the result of the study indicated, there was a negative significant relationship between the student's social intelligence and aggression. Menurut Shekarey, et al (2013 hasil penelitian ini sejalan dengan hasil penelitian yang dilakukan oleh Dibo \& Pirnis (2006), Bazargan and et al. (2004), Ka'fai and et al. (2009), Sadeghi and et al (2002), Cohen (1976) and Berkowitz (1973). Hasil penelitian Parto, Arofzad, dan Taghi (2013) menyimpulkan "that the significant and meaningful correlations between overall social intelligence scores and effective influence subscales. Thus, the strength of the correlations obtained in the present research suggests that the overall social intelligence has a significant role in the effective influence". Di samping itu Hopword (tt) dalam kajiannya tentang hubungan antara kecerdasan sosial dengan proses kreatif, menyimpulkan adanya keterkaitan antara kecerdasan sosial dengan proses kreatif.

Kecerdasan sosial berhubungan dengan sensivitas dalam komunikasi interkultural (Dong, Koper, dan Collaco, 2008). Sebagaimana juga dikemukakanoleh Hamid dan Eftekhar (2016) bahwa siswa dengan kecerdasan sosial yang tinggi memiliki pemahaman yang besar terhadap perasaan dan keinginan orang, serta dapat beradaptasi dengan mudah dengan orang lain.

Kehidupan karir juga membutuhkan kecerdasan sosial. Beheshtifer dan Roasaei $(2012,2015)$ menyatakan bahwa menejer dengan kecerdasan sosial yang tinggi tampaknya mengalami kesuksesan dalam kerjasama, pemecahan masalah, dan meningkatkan kreativitas orang-orang yang dipimpinnya. Sebagaimana pendapat Phipps bahwa kecerdasan sosial merupakan kunci komunikasi dan inovasi di tempat kerja (Beheshtifer dan Roasaei (2012, 2015).

Bertitik tolak dari pentingnya kecerdasan sosial bagi kehidupan siswa, maka upaya pengembangan kecerdasan sosial, khususnya pada siswa sekolah menengah pertama perlu dilakukan secara sistematis dan berkelanjutan. Berkenan dengan upaya dimaksud maka dibutuhkan panduan yang dapat dijadikan sebagai pedoman bagi guru bimbingan dan konseling dalam mengembangkan kecerdasan sosial siswa sekolah menengah pertama.

\section{METODE}

Prosedur penelitian yang digunakan adalah prosedur penelitian pengembangan menurut Borg dan Gall (1983), yang dirinci dalam 5 langkah utama, yakni: (1) Langkah I: Analisis produk awal yang akan dikembangkan, yang meliputi kegiatan: (a) mengetahui pelaksanaan layanan bimbingan dan konseling yang dilaksanakan oleh guru bimbingan dan konseling untuk meningkatkan kecerdasan sosial siswa SMP, dan (b) mengidentifikasi kecerdasan sosial siswa SMP; (2) Langkah II, mengembangkan produk awal, yang meliputi kegiatan: pengembangan draft awal produk, yang meliputi: (a) draft silabus Layanan dan Rencana Pelaksanaan Layanan Bimbingan dan Konseling (RPLBK), (b) draft panduan guru, (c) draft materi layanan, dan (d) draft panduan evaluasi; (3) langkah III, validasi ahli dan revisi, yang meliputi kegiatan: (a) pengembangan instrumen validasi ahli, masing-masing untuk: ahli bimbingan dan konseling, ahli psikologi perkembangan, ahli desain, dan ahli bahasa Indonesia; (b) validasi instrumen oleh teman sejawat, (c) validasi ahli dengan menggunakan instrumen yang telah divalidasi, (d) analisis data dan revisi produk 
berdasarkan data hasil validasi ahli; (4) langkah IV, uji coba lapangan kelompok kecil dengan subyek 3 orang guru bimbingan dan konseling dan revisi produk, serta uji coba kelompok besar dengan subyek 9 orang guru bimbingan dan konseling dilanjutkan dengan revisi produk. Pada langkah ini dihasilkan produk akhir panduan, yang terdiri dari: (a) Silabus Layanan dan Rencana Pelaksanaan Layanan Bimbingan dan Konseling (RPLBK), (b) Panduan Guru, (c) Materi Layanan, dan (d) Panduan Evaluasi.

Subyek untuk validasi ahli terdiri dari 4 orang pakar, yang terdiri dari pakar bimbingan dan konseling, pakar psikologi, pakar bahasa Indonesia, dan pakar desain. Uji coba kelompok kecil dilakukan oleh subyek sebanyak 3 orang guru bimbingan dan konseling, masing-masing 1 orang dari SMP Negeri 1 Gorontalo, 1 orang SMP Negeri 4 Gorontalo, dan 1 orang dari SMP Negeri 8 Gorontalo. Uji kelompok besar dilakukan oleh subyek sebanyak 9 orang guru bimbingan dan konseling, masing-masing 3 orang dari SMP Negeri 2 Gorontalo, 3 orang dari SMP Negeri 3 Gorontalo, dan 3 orang dari SMP Negeri 10 Gorontalo. Pengumpulan data dilakukan dengan menggunakan instrumen angket, yang terdiri dari angket tebuka untuk validasi pakar, dan angket tertutup untuk untuk uji coba kelompok kecil dan uji coba kelompok besar. Analisis data hasil validasi pakar dilakukan secara kualitatif, dan analisis data hasil uji kelompok kecil dan uji kelompok besar dilakukan secara kuantitatif dan kualitatif.

\section{HASIL DAN PEMBAHASAN}

Validasi ahli Bimbingan dan Konseling dilakukan untuk menilai Buku1, Buku 2, Buku 3, dan Buku 4. Komponen yang dinilai dalam Buku 1 ini meliputi Program Tahunan dan Rencana Pelaksanaan Layanan Bimbingan dan Konseling (RPLBK). Berikut adalah hasil validasi ahli bimbingan dan konseling:

a) Program Tahunan

Judul, domain perkembangan/bidang bimbingan dan konseling: rumusan tujuan, standar kompetensi, komponen program dan srategi yang telah ditetapkan sudah sesuai dengan aspek dan dapat mendukung pengembangan kecerdasan sosial siswa. Namun metode evaluasi yang telah ditetapkan belum dapat mengukur perkembangan kecerdasan sosial dengan alasan sebaiknya metode evaluasi menggunakan (1) penilaian segera, (2) penilaian jangka pendek, (3) penilaian jangka panjang.

b) Rencana Pelaksanaan Layanan Bimbingan dan Konseling (RPLBK):

Penetapan topik permasalahan, bidang bimbingan, jenis layanan, fungsi layanan, tujuan layanan, srategi layanan, metode/teknik, uraian kegiatan, materi layanan, media layanan, penyelenggara layanan, pihak-pihak yang dilibatkan, rencana penilaian, tindak lanjut, dan lampiran pada setiap RPL sudah sesuai dengan kegiatan yang dilaksanakan dalam upaya membantu siswa mengembangkan kecerdasan sosial siswa.

Komponen yang dinilai dalam Buku 2 ini meliputi: deskripsi, hasil yang diharapkan, komponen layanan, strategi layanan, media dan fasilitas, evaluasi. Berikut adalah hasil validasi ahli bimbingan dan konseling: (a) Bagian deskripsi pada setiap topik telah dapat memberikan gambaran kepada guru tentang kegiatan layanan yang akan dilaksanakannya. (b) Rumusan masalah yang disusun akan dapat dicapai oleh siswa. (c) Komponen layanan yang telah ditetapkan akan dapat membantu siswa mengembangakan kecerdasan sosial siswa. (d) Strategi layanan yang telah disusun akan dapat membantu siswa mengem-bangkan kecerdasan sosial; (e) Media dan fasilitasi telah sesuai dengan aktivitas layanan; (f) Teknik evaluasi yang disusun akan dapat mengukur perkembangan kecerdasan sosial siswa.

Komponen yang dinilai dalam buku 3 ini meliputi: deskripsi, daftar rujukan, pengantar, petunjuk tugas individual, petunjuk tugas kelompok, dan petunjuk latihan. Buku ini berisi 8 topik. Berikut adalah hasil validasi ahli bimbingan dan konseling: 
Tabel 3.1 Validasi Buku 3 oleh Ahli Bimbingan Konseling

\begin{tabular}{|c|c|c|c|c|c|c|c|c|c|}
\hline No. & $\begin{array}{c}\text { Aspek yang } \\
\text { Dinilai }\end{array}$ & $\begin{array}{c}\text { Topik } \\
1\end{array}$ & $\begin{array}{l}\text { Topik } \\
2\end{array}$ & $\begin{array}{c}\text { Topik } \\
\mathbf{3}\end{array}$ & $\begin{array}{c}\text { Topik } \\
4\end{array}$ & $\begin{array}{c}\text { Topik } \\
5\end{array}$ & $\begin{array}{c}\text { Topik } \\
6\end{array}$ & $\begin{array}{c}\text { Topik } \\
7\end{array}$ & $\begin{array}{c}\text { Topik } \\
8\end{array}$ \\
\hline 1. & $\begin{array}{l}\text { Deskripsi pada } \\
\text { topik dapat } \\
\text { memotivasi siswa } \\
\text { dan guru untuk } \\
\text { membaca buku ini } \\
\text { secara } \\
\text { keseluruhan }\end{array}$ & $\mathrm{Ya}$ & $\mathrm{Ya}$ & $\mathrm{Ya}$ & $\mathrm{Ya}$ & $\mathrm{Ya}$ & $\mathrm{Ya}$ & $\mathrm{Ya}$ & $\mathrm{Ya}$ \\
\hline 2. & $\begin{array}{l}\text { Daftar rujukkan } \\
\text { sesuai dengan } \\
\text { materi/topic }\end{array}$ & Ya & Ya & Ya & Ya & Ya & Ya & Ya & Ya \\
\hline 3. & $\begin{array}{l}\text { Kalimat pengantar } \\
\text { dapat memotivasi } \\
\text { siswa untuk } \\
\text { mengembangkan } \\
\text { kemampuan } \\
\text { berempati }\end{array}$ & Ya & Ya & $\mathrm{Ya}$ & Ya & Ya & Ya & Ya & Ya \\
\hline 4. & $\begin{array}{l}\text { Uraian materi } \\
\text { mudah dipahami } \\
\text { oleh siswa dan } \\
\text { guru }\end{array}$ & Ya & Tidak & Ya & Ya & Ya & Ya & $\mathrm{Ya}$ & Ya \\
\hline 5. & $\begin{array}{l}\text { Materi yang } \\
\text { diuraikan dalam } \\
\text { buku ini dapat } \\
\text { memberikan } \\
\text { informasi praktis } \\
\text { bagi para siswa } \\
\text { tentang empati }\end{array}$ & Ya & Ya & $\mathrm{Ya}$ & Ya & Ya & Ya & $\mathrm{Ya}$ & Ya \\
\hline 6. & $\begin{array}{l}\text { Petunjuk tugas } \\
\text { individual mudah } \\
\text { dipahami oleh } \\
\text { siswa dan guru }\end{array}$ & Ya & Ya & Ya & $\mathrm{Ya}$ & Ya & Ya & $\mathrm{Ya}$ & Ya \\
\hline 7. & $\begin{array}{l}\text { Petunjuk tugas } \\
\text { kelompok mudah } \\
\text { dipahami oleh } \\
\text { siswa dan guru }\end{array}$ & Ya & Ya & Ya & $\mathrm{Ya}$ & Ya & Ya & $\mathrm{Ya}$ & Ya \\
\hline 8. & $\begin{array}{l}\text { Petunjuk latihan } \\
\text { mudah dipahami } \\
\text { siswa }\end{array}$ & Ya & Ya & Ya & Ya & Ya & Ya & $\mathrm{Ya}$ & $\mathrm{Ya}$ \\
\hline 9. & $\begin{array}{l}\text { Kegiatan latihan } \\
\text { dapat dilakukan } \\
\text { siswa untuk } \\
\text { melatih } \\
\text { mengembangkan } \\
\text { empati siswa }\end{array}$ & Ya & Ya & Ya & $\mathrm{Ya}$ & Ya & Ya & $\mathrm{Ya}$ & $\mathrm{Ya}$ \\
\hline
\end{tabular}

Komponen yang dinilai dalam buku 4 ini meliputi: butir-butir/item instrument, petunjuk skoring, dan klasifikasi penilaian. Berikut adalah hasil validasi ahli bimbingan dan konseling: (a)
Butir-butir instrument dengan indikator empati dasar, penyelarasan, ketepatan empatik, pengertian sosial, sinkronisasi, presentasi, pengaruh, dan kepedulian siswa yang disusun 
telah dapat mengukur kemampuan empati dasar, penyelarasan, ketepatan empatik, pengertian sosial, sinkronisasi, presentasi, pengaruh, dan kepedulian siswa. (b) Petunjuk skoring telah sesuai dengan prinsip-prinsip penilaian. (c) Rentangan klasifikasi penilaian telah menunjukkan keseimbangan skor.
Validasi ahli rancangan dilakukan untuk menilai: desain fisik cover, gambar, bentuk huruf, sistematika materi, teknik pengetikan, warna, tampilan buku secara umum terhadap Buku 1, Buku 2, Buku 3, dan Buku 4 yang telah disusun. Berikut adalah hasil validasi ahli rancangan:

Tabel 3.2 Validasi Ahli Rancangan

\begin{tabular}{|c|c|c|c|c|c|}
\hline No. & Aspek Penilaian & $\begin{array}{c}\text { Buku } \\
1\end{array}$ & $\begin{array}{c}\text { Buku } \\
2\end{array}$ & $\begin{array}{c}\text { Buku } \\
3\end{array}$ & $\begin{array}{c}\text { Buku } \\
4\end{array}$ \\
\hline 1. & $\begin{array}{l}\text { Desain fisik cover pada setiap buku dapat menimbulkan } \\
\text { kriteria siswa untuk membaca buku }\end{array}$ & $\mathrm{Ya}$ & $\mathrm{Ya}$ & Ya & $\mathrm{Ya}$ \\
\hline 2. & $\begin{array}{l}\text { Bentuk huruf yang digunakan pada cover setiap buku } \\
\text { dapat menimbulkan ketertarikan siswa dan guru untuk } \\
\text { membaca buku }\end{array}$ & $\mathrm{Ya}$ & Ya & Ya & $\mathrm{Ya}$ \\
\hline 3. & $\begin{array}{l}\text { Bentuk huruf yang digunakan pada tulisan di halaman- } \\
\text { halaman dalam buku dapat menimbulkan ketretarikan } \\
\text { siswa dan guru untuk membaca uraian pada halaman- } \\
\text { halaman tersebut }\end{array}$ & $\mathrm{Ya}$ & $\mathrm{Ya}$ & $\mathrm{Ya}$ & $\mathrm{Ya}$ \\
\hline 4. & $\begin{array}{l}\text { Gambar pada cover pada setiap buku dapat mewakili } \\
\text { substansi topik yang dibahas }\end{array}$ & $\mathrm{Ya}$ & $\mathrm{Ya}$ & $\mathrm{Ya}$ & $\mathrm{Ya}$ \\
\hline 5. & $\begin{array}{l}\text { Sistematikan materi yang diuraikan telah sesuai dengan } \\
\text { topik }\end{array}$ & $\mathrm{Ya}$ & Ya & Ya & $\mathrm{Ya}$ \\
\hline 6. & $\begin{array}{l}\text { Teknik pengetikan isi buku akan menarik siswa dan } \\
\text { guru untuk membaca buku }\end{array}$ & Ya & Ya & Ya & $\mathrm{Ya}$ \\
\hline 7. & $\begin{array}{l}\text { Apakah bentuk huruf rapih, menarik dan mudah dibaca } \\
\text { oleh siswa dan guru }\end{array}$ & $\mathrm{Ya}$ & Ya & Ya & $\mathrm{Ya}$ \\
\hline 8. & $\begin{array}{l}\text { Warna-warna yang digunakan dalam desain buku dapat } \\
\text { menarik siswa dan guru untuk membaca buku }\end{array}$ & $\mathrm{Ya}$ & $\mathrm{Ya}$ & Ya & $\mathrm{Ya}$ \\
\hline 9. & $\begin{array}{l}\text { Tampilan keseluruhan dari buku dapat memotivasi } \\
\text { siswa dan guru untuk membaca buku }\end{array}$ & $\mathrm{Ya}$ & $\mathrm{Ya}$ & $\mathrm{Ya}$ & $\mathrm{Ya}$ \\
\hline
\end{tabular}

Validasi ahli Bahasa Indonesia dilakukan untuk menilai Buku 1, Buku 2, Buku 3, dan Buku 4.

Komponen yang dinilai dalam Buku 1 ini meliputi cover, Program Tahunan, Rencana Pelaksanaan Layanan Bimbingan dan Konseling (RPLBK). Berikut adalah hasil validasi ahli Bahasa Indonesia: (a) Cover; Bentuk huruf dan ukuran huruf yang digunakan pada cover buku dapatmenimbulkan minat guru unuk membaca buku panduan. Teknik penulisan kata dan kalimat pada cover belum sesuai dengan kaidah penulisan bahasa Indonesia baku, dengan alasan Sekolah Menengah Pertama tidak dapat disingkat SMP; (b) Program Tahunan, Penulisan kata/kalimat pada kolom program, domain perkembangan, tujuan, standar kompetensi, komponen program/layanan, target siswa, dan metode evaluasi telah sesuai dengan kaidah penulisan Bahasa Indonesia baku dan mudah dipahami guru. (c) Rencana Pelaksanaan Layanan Bimbingan dan Konseling (RPLBK), Penulisan kata/kalimat yang digunakan pada: topik permasalahan, bidang bimbingan, jenis layanan, fungsi layanan, tujuan layanan, sasaran layanan, strategi, metode/teknik, uraian kegiatan, materi layanan, media layanan, tempat penyelenggaraan, penyelenggara layanan, pihakpihak yang dilibatkan, dan rencana penilaian, telah sesuai dengan kaidah penulisan Bahasa Indonesia baku dan mudah dipahami guru.

Validasi ahli bahasa dilakukan untuk menilai cover, isi buku yang terdiri dari: (a) deskripsi, (b) daftar rujukan, (c) pengantar, (d) petunjuk tugas individual, (e) petunjuk tugas kelompok, dan (f) petunjuk latihan. Berikut adalah hasil validasi ahli bahasa: (a) Cover, Bentuk dan ukuran huruf yang digunakan pada cover buku sudah dapat menimbulkan minat guru untuk membaca buku panduan ini. Teknik 
penulisan kata dan kalimat pada cover belum sesuai dengan kaidah penulisan bahasa Indonesia bakudengan alasan Sekolah Menengah Pertama tidak dapat disingkat SMP, (b) Isi buku, Kata/kalimat yang digunakan di bagian deskripsi, daftar rujukan, pengantar, uraian materi, petunjuk tugas individual, dan petunjuk tugas kelompok telah sesuai dengan kaidah penulisan bahasa Indonesia baku dan mudah dipahami oleh siswa dan guru. Sedangkan di bagian petunjuk latihan dinilai tidak mudah dipahami oleh guru dan siswa dengan alasan tidak ditemukan halaman petunjuk latihan pada buku panduan buku 2 .

Validasi ahli bahasa pada buku 3 dilakukan untuk menilai Cover, pengantar, topiktopik tentang komponen kecerdasan sosial. Isi tiap topik terdiri dari: (a) deskripsi topik yang dibahas, (b) hasil yang diharapkan, (c) komponen layanan, (d) strategi layanan, (e) media dan fasilitas, dan (f) evaluasi. Berikut adalah hasil validasi ahli bahasa: (a) Cover, Bentuk dan ukuran huruf yang digunakan pada cover buku dinilai dapat menimbulkan minat guru untuk membaca buku panduan ini, dan teknik penulisan kata dan kalimat pada cover sudah sesuaidengan kaidah penulisan Bahasa Indonesia baku; (b) Isi Panduan, Kalimat yang digunakan pada bagian pengantar sudah sesuai dengan kaidah penulisan bahasa Indonesia baku, dan kalimat yang digunakan pada bagian pengantar mudah dipahami oleh guru' (c) Uraian setiap Topik

Tabel3.3 Validasi Buku 3 Oleh Ahli Bahasa

\begin{tabular}{|c|c|c|c|c|c|c|c|c|c|}
\hline No. & $\begin{array}{c}\text { Aspek yang } \\
\text { Dinilai }\end{array}$ & $\begin{array}{c}\text { Topik } \\
1\end{array}$ & $\begin{array}{l}\text { Topik } \\
2\end{array}$ & $\begin{array}{c}\text { Topik } \\
\mathbf{3}\end{array}$ & $\begin{array}{c}\text { Topik } \\
4\end{array}$ & $\begin{array}{c}\text { Topik } \\
5\end{array}$ & $\begin{array}{c}\text { Topik } \\
6\end{array}$ & $\begin{array}{c}\text { Topik } \\
7\end{array}$ & $\begin{array}{l}\text { Topik } \\
8\end{array}$ \\
\hline 1. & $\begin{array}{l}\text { Kalimat yang } \\
\text { digunakan pada } \\
\text { "deskripsi topik" } \\
\text { sesuai dengan } \\
\text { kalimat bahasa } \\
\text { Indonesia baku }\end{array}$ & $\mathrm{Ya}$ & $\mathrm{Ya}$ & $\mathrm{Ya}$ & $\mathrm{Ya}$ & $\mathrm{Ya}$ & $\mathrm{Ya}$ & $\mathrm{Ya}$ & $\mathrm{Ya}$ \\
\hline 2. & $\begin{array}{l}\text { Kalimat yang } \\
\text { digunakan pada } \\
\text { deskripsi topik } \\
\text { dapat dipahami } \\
\text { oleh guru }\end{array}$ & Ya & Ya & Ya & $\mathrm{Ya}$ & $\mathrm{Ya}$ & Ya & $\mathrm{Ya}$ & $\mathrm{Ya}$ \\
\hline 3. & $\begin{array}{l}\text { Kalimat yang } \\
\text { digunakan pada } \\
\text { rumusan "hasil } \\
\text { yang diharapkan" } \\
\text { sesuai dengan } \\
\text { kaidah penulisan } \\
\text { bahasa Indonesia } \\
\text { baku }\end{array}$ & Ya & Ya & Ya & Ya & $\mathrm{Ya}$ & $\mathrm{a}$ & $\mathrm{Ya}$ & Ya \\
\hline 4. & $\begin{array}{l}\text { Kalimat yang } \\
\text { digunakan pada } \\
\text { rumusan "hasil } \\
\text { yang diharapkan" } \\
\text { mudah dipahami } \\
\text { oleh guru }\end{array}$ & Ya & Tidak & Ya & Ya & $\mathrm{Ya}$ & $\mathrm{Ya}$ & $\mathrm{Ya}$ & Ya \\
\hline 5. & $\begin{array}{l}\text { Kalimat yang } \\
\text { digunakan pada } \\
\text { "strategi layanan" } \\
\text { sesuai dengan } \\
\text { kaidah penulisan } \\
\text { bahasa Indonesia } \\
\text { baku }\end{array}$ & Ya & Ya & Ya & $\mathrm{Ya}$ & $\mathrm{Ya}$ & Ya & Ya & Ya \\
\hline
\end{tabular}




\begin{tabular}{|c|c|c|c|c|c|c|c|c|c|}
\hline No. & $\begin{array}{l}\text { Aspek yang } \\
\text { Dinilai }\end{array}$ & $\begin{array}{c}\text { Topik } \\
1\end{array}$ & $\begin{array}{c}\text { Topik } \\
2\end{array}$ & $\begin{array}{c}\text { Topik } \\
\mathbf{3}\end{array}$ & $\begin{array}{c}\text { Topik } \\
4\end{array}$ & $\begin{array}{c}\text { Topik } \\
5\end{array}$ & $\begin{array}{c}\text { Topik } \\
6 \\
\end{array}$ & $\begin{array}{c}\text { Topik } \\
7 \\
\end{array}$ & $\begin{array}{c}\text { Topik } \\
8\end{array}$ \\
\hline 6. & $\begin{array}{l}\text { Kalimat yang } \\
\text { digunakan pada } \\
\text { "stretegi layanan" } \\
\text { mudah dipahami } \\
\text { oleh guru }\end{array}$ & Ya & Ya & $\mathrm{Ya}$ & $\mathrm{Ya}$ & $\mathrm{Ya}$ & $\mathrm{Ya}$ & $\mathrm{Ya}$ & $\mathrm{Ya}$ \\
\hline 7. & $\begin{array}{l}\text { Kalimat yang } \\
\text { digunakan pada } \\
\text { "fasilitas dan } \\
\text { media" sesuai } \\
\text { dengan kaidah } \\
\text { penulisan bahasa } \\
\text { Indonesia baku }\end{array}$ & Ya & $\mathrm{Ya}$ & Ya & Ya & Ya & Ya & Ya & Ya \\
\hline 8. & $\begin{array}{l}\text { Kalimat yang } \\
\text { digunakan pada } \\
\text { "fasilitas dan } \\
\text { media" mudah } \\
\text { dipahami oleh } \\
\text { guru }\end{array}$ & Ya & $\mathrm{Ya}$ & Ya & Ya & Ya & Ya & Ya & Ya \\
\hline 9. & $\begin{array}{l}\text { Kalimat yang } \\
\text { digunakan pada } \\
\text { "evaluasi" sesuai } \\
\text { dengan kaidah } \\
\text { penulisan bahasa } \\
\text { Indonesia baku }\end{array}$ & Ya & Ya & Ya & Ya & Ya & Ya & Ya & Ya \\
\hline 10. & $\begin{array}{l}\text { Kalimat yang } \\
\text { digunakan pada } \\
\text { "evaluasi" mudah } \\
\text { dipahami oleh } \\
\text { guru }\end{array}$ & Ya & Ya & Ya & Ya & Ya & Ya & Ya & Ya \\
\hline
\end{tabular}

Validasi ahli bahasa dilakukan pada buku 4, menilai: Cover Buku, Isi Buku, yang terdiri dari: (a) pengantar, (b) komponen panduan, (c) tujuan evaluasi, (d) pelaksanaan evaluasi, (e) instrument pada setiap akhir kegiatan indikator kecerdasan sosial, (f) instrument pada akhir seluruh kegiatan layanan, (g) petunjuk penyekoran, dan (h) klasifikasi penilaian.

Hasiil penilaian yaitu: (a) Cover, Bentuk dan ukuran huruf yang digunakan pada cover buku dinilai dapat menimbulkan minat guru untuk membaca buku panduan, teknik penulisan kata dan kalimat pada cover sudah sesuai dengan kaidah penulisan Bahasa Indonesia baku; (b) Isi
Buku, Penulisan kata/kalimat pada bagian pengantar, komponen panduan, tujuan evaluasi, pelaksanaan evaluasi, instrument pada setiap akhir kegiatan indikator kecerdasan sosial, instrument pada akhir seluruh kegiatan layanan, petunjuk penyekoran, dan klasifikasi penilaian telah sesuai dengan kaidah penulisan bahasa Indonesia baku serta mudah dipahami oleh siswa dan guru.

Validasi ahli psikologi khusus dilakukan untuk memvalidasi buku 3 untuk menilai: deskripsi, daftar rujukan, pengantar, petunjuk tugas individual, petunjuk tugas kelompok dan petunjuk latihan pada 8 topik yang disusun. Berikut adalah hasil validasi ahli psikologi: 
Tabel 3.4 Validasi Buku 3 oleh Ahli Bahasa

\begin{tabular}{|c|c|c|c|c|c|c|c|c|c|}
\hline No. & Aspek yang Dinilai & $\begin{array}{c}\text { Topik } \\
1\end{array}$ & $\begin{array}{c}\text { Topik } \\
2\end{array}$ & $\begin{array}{c}\text { Topik } \\
\mathbf{3}\end{array}$ & $\begin{array}{c}\text { Topik } \\
\mathbf{4}\end{array}$ & $\begin{array}{c}\text { Topik } \\
5\end{array}$ & $\begin{array}{c}\text { Topik } \\
6\end{array}$ & $\begin{array}{c}\text { Topik } \\
7\end{array}$ & $\begin{array}{c}\text { Topik } \\
8\end{array}$ \\
\hline 1. & $\begin{array}{l}\text { Kalimat yang digunakan pada } \\
\text { "deskripsi topik" sesuai } \\
\text { dengan kalimat bahasa } \\
\text { Indonesia baku }\end{array}$ & $\mathrm{Ya}$ & Ya & $\mathrm{Ya}$ & $\mathrm{Ya}$ & $\mathrm{Ya}$ & $\mathrm{Ya}$ & $\mathrm{Ya}$ & $\mathrm{Ya}$ \\
\hline 2. & $\begin{array}{l}\text { Kalimat yang digunakan pada } \\
\text { deskripsi topik dapat } \\
\text { dipahami oleh guru }\end{array}$ & Ya & $\mathrm{Ya}$ & Ya & Ya & Ya & $\mathrm{Ya}$ & Ya & Ya \\
\hline 3. & $\begin{array}{l}\text { Kalimat yang digunakan pada } \\
\text { rumusan "hasil yang } \\
\text { diharapkan" sesuai dengan } \\
\text { kaidah penulisan bahasa } \\
\text { Indonesia baku }\end{array}$ & Ya & $\mathrm{Ya}$ & Ya & Ya & Ya & $\mathrm{Ya}$ & Ya & Ya \\
\hline 4. & $\begin{array}{l}\text { Kalimat yang digunakan pada } \\
\text { rumusan "hasil yang } \\
\text { diharapkan" mudah dipahami } \\
\text { oleh guru }\end{array}$ & Ya & Tidak & Ya & Ya & Ya & $\mathrm{Ya}$ & Ya & Ya \\
\hline 5. & $\begin{array}{l}\text { Kalimat yang digunakan pada } \\
\text { "strategi layanan" sesuai } \\
\text { dengan kaidah penulisan } \\
\text { bahasa Indonesia baku }\end{array}$ & Ya & $\mathrm{Ya}$ & $\mathrm{Ya}$ & Ya & Ya & $\mathrm{Ya}$ & $\mathrm{Ya}$ & Ya \\
\hline 6. & $\begin{array}{l}\text { Kalimat yang digunakan pada } \\
\text { "stretegi layanan" mudah } \\
\text { dipahami oleh guru }\end{array}$ & Ya & Ya & Ya & Ya & Ya & $\mathrm{Ya}$ & $\mathrm{Ya}$ & Ya \\
\hline 7. & $\begin{array}{l}\text { Kalimat yang digunakan pada } \\
\text { "fasilitas dan media" sesuai } \\
\text { dengan kaidah penulisan } \\
\text { bahasa Indonesia baku }\end{array}$ & Ya & Ya & Ya & Ya & Ya & $\mathrm{Ya}$ & $\mathrm{Ya}$ & Ya \\
\hline 8. & $\begin{array}{l}\text { Kalimat yang digunakan pada } \\
\text { "fasilitas dan media" mudah } \\
\text { dipahami oleh guru }\end{array}$ & Ya & Ya & Ya & Ya & Ya & $\mathrm{Ya}$ & $\mathrm{Ya}$ & Ya \\
\hline 9. & $\begin{array}{l}\text { Kalimat yang digunakan pada } \\
\text { "evaluasi" sesuai dengan } \\
\text { kaidah penulisan bahasa } \\
\text { Indonesia baku }\end{array}$ & Ya & Ya & Ya & Ya & Ya & $\mathrm{Ya}$ & $\mathrm{Ya}$ & Ya \\
\hline 10. & $\begin{array}{l}\text { Kalimat yang digunakan pada } \\
\text { "evaluasi" mudah dipahami } \\
\text { oleh guru }\end{array}$ & Ya & Ya & Ya & Ya & Ya & $\mathrm{Ya}$ & $\mathrm{Ya}$ & Ya \\
\hline
\end{tabular}

Validasi ahli psikologi memberikan catatan penting tentang perlunya penggunaan contoh-contoh konkrit dalam kehidupan siswa pada setiap topik, agar siswa lebih mudah memahami konsep yang dijelaskan.

\section{Revisi Berdasarkan Validasi Ahli dan Produk Akhir}

Berdasarkan data yang diperoleh melalui validasi ahli terhadap draft panduan yang telah disusun, selanjutnya dilakukan revisi terhadap draft panduan tersebut. Revisi dilakukan dengan memperbaiki aspek-aspek yang dinilai oleh para ahli "belum tepat" atau "masih perlu diperbaiki". Kegiatan revisi ini menghasilkan produk akhir panduan untuk meningkatkan kompetensi guru bimbingan dan konseling mengembangkan kecerdasan sosial siswa SMP kelas VII, yang terdiri dari: (1) Buku 1: Silabus Layanan dan Rencana Pelaksanaan Layanan Bimbingan dan Konseling, (2) Buku 2: Panduan Guru, (3) Buku 
3: Materi Layanan, dan (4) Buku 4: Panduan Evaluasi.

\section{Uji Coba Kelompok Kecil dan Uji Kelompok Besar}

Pada tahap ini dilakukan uji coba kelompok kecil terhadap produk panduan yang telah dihasilkan. Uji kelompok kecil dilakukan oleh 3 orang guru bimbingan dan konseling, dan Buku 2: Panduan Guru,(3) Buku 3: Materi Layanan, dan (4) Buku 4: Panduan Evaluasi. Berdasarkan hasil analisis data secara kualitatif, diperoleh data bahwa semua aspek yang tercakup dalam panduan tersebut "mudah dibaca" dan "mudah dipahami", sehingga tidak perlu dilakukan revisi pada semua aspek yang dinilai.

Kegiatan uji kelompok kecil dan uji kelompok besar ini menghasilkan produk akhir panduan untuk meningkatkan kompetensi guru bimbingan dan konseling dalam mengembangkan kecerdasan sosial siswa SMP kelas VII, yang terdiri dari: (1) Buku 1: Silabus Layanan dan Rencana Pelaksanaan Layanan Bimbingan dan Konseling, (2) Buku 2: Panduan Guru, (3) Buku 3: Materi Layanan, dan (4) Buku 4: Panduan Evaluasi.

Penelitian ini telah menghasilkan panduan layanan bimbingan dan konseling untuk mengembangkan kecerdasan sosial siswa SMP kelas VII, yang terdiri dari: (1) Buku 1: Silabus Layanan dan 15 buah Rencana Pelaksanaan Layanan Bimbingan dan Konseling, (2) Buku 2: Panduan Guru, (3) Buku 3: Materi Layanan, dan (4) Buku 4: Panduan Evaluasi.

Kecerdasan sosial dibutuhkan siswa dalam kehidupannya sebagai pribadi, dan terutama sebagai bagian dari anggota masyarakat (sebagai makhluk sosial). Beberapa hasil penelitian telah menemukan adanya korelasi dan kontribusi kecerdasan sosial terhadap aktivitas dan perilaku siswa serta individu pada umumnya. Shekarey, et al (2013) melalui penelitiannya menyimpulkan "that there was a negative and significant relationship between the student's social intelligence and their aggressive behaviors. In other words, the students having high social intelligence are calm and they indicate less aggressive behaviors. As the result of the study indicated, there was a negative significant relationship between the student's social intelligence and aggression. Menurut Shekarey, et al (2013 hasil penelitian ini sejalan dengan hasil penelitian yang dilakukan oleh Dibo \& Pirnis (2006), Bazargan and et al. (2004), uji kelompok besar dilakukan oleh 9 orang guru bimbingan dan konseling, dengan maksud untuk menilai "keterbacaan" dan "pemahaman" isi panduan, yakni aspek-aspek yang tercakup dalam panduan yang telah disusun. Panduan yang dinilai terdiri dari: (1) Buku 1: Program Layanan dan Rencana Pelaksanaan Layanan Bimbingan dan Konseling, (2)

Ka'fai and et al. (2009), Sadeghi and et al (2002), Cohen (1976) and Berkowitz (1973). Selain itu, hasil penelitian Baggiyam dan Pankajan (2017); Asma; Tasleema dan Gani (2015); Manullang (2015); dan Wulandari (2014) menunjukkan terdapat korelasi positif antara kecerdasan sosial dengan prestasi akademik.

Bertitik tolak dari pentingnya kecerdasan sosial bagi kehidupan siswa, maka upaya pengembangan kecerdasan sosial, khususnya pada siswa sekolah menengah pertama perlu dilakukan secara sistematis dan berkelanjutan. Berkenaan dengan upaya dimaksud maka panduan yang dikembangkan melalui penelitian ini dapat dijadikan sebagai pedoman bagi guru bimbingan dan konseling dalam mengembangkan kecerdasan sosial siswa sekolah menengah pertama.

\section{SIMPULAN DAN SARAN}

Penelitian ini telah menghasilkan panduan bimbingan dan konseling untuk mengembangkan kecerdasan sosial siswa sekolah menengah pertama, yang terdiri dari: (1) Buku 1: Silabus Layanan dan Rencana Pelaksanaan Layanan Bimbingan dan Konseling, (2) Buku 2: Panduan Guru, (3) Buku 3: Materi Layanan, dan (4) Buku 4: Panduan Evaluasi.

Panduan ini dikembangkan dengan menggunakan metode penelitian dan pengembangan (Research \& Development), oleh sebab itu panduan ini dapat direkomendasikan untuk digunakan para guru bimbingan dan konseling/konselor dalam melaksanakan layanan untuk pengembangan kecerdasan sosial siswa, khususnya siswa sekolah menengah pertama.

\section{DAFTAR RUJUKAN}

Asma, Nazier; Tasleema; Gani. (2015). Social Intelligence and Academic Achievement of College Studetns. A Study of District Srinagar. ISQR Journal of Humanisties 
and Social Science (ISQR-JHHS) vol.20, Issue 2, Vol. II (feb.2015), pp 74-76

Baggiyam, Dhana, dan Pakajan, R. (2017). Social Intelligence in Relationto Academic Achievement. International Journal of Research-Granthaalayah, 5(3) SE, 1822.

http://doi.org//10.5281/zenodo.545958

Bakhtiar,I. (2015) Pengembangan Video Ice Breaking Sebagai Media Bimbingan Konseling Dalam Meningkatkan Keterampilan Sosial. Jurnal Psikologi Pendidikan dan Konseling. 2(1). pp(150-152)

Beheshtifar, Malikeh dan Fateme Roasaei. (2012). Role of Social Intelligence in Organizational Leadership. European Journal of Social Science, vol. 28 No. 2 (2012),pp. 200-206.

Dong, Qingwen; Randall, J. Koper; Christine M. Collaco. (2008). Social Intelligence, Self-Esteem, and Intercultural Communication Sensivity. International Communication Studies XVII: 2 2008, 162-172.

Parto; Arofzad, Sharam; Taghi Agha Hosaini. (2013). Relationship between social intelligence with effective influence among physical education expertice in Isfahan education organizations. Europen Journal of Experimental Biology, 2013, 3(3): 168-172.

Hopword, Jon. (tt). Social Intelligence and the Creative Process. Institute of Live Communications, Melbourne, Australia.
Manullang, Resi. (2015). Pengaruh Kecerdasan Sosial terhadap Prestasi Belajar Siswa di SMK Negeri 2 Kota Jambi. Jurnal Ilmia Universitas Batanghari jambi, Vol.15 N0. 3 Tahun 2015.

Rahim, Maryam; Irvan Usman; Meiske Puluhulawa. 2017. Kecerdasan Sosial dan Prestasi Belajar Siswa (Tinjauan dari Persfektif Bimbingan dan Konseling Belajar). Artikel yang Disajikan padaSeminar dan Lokakarya Nasional "Revitalisasi Laboratorium dan Jurnal Ilmiah dalam Implementasi Kurikulum Bimbingan dan Konseling Berbasis KKNI", tanggal 4-6 Agustus 2017, di Universitas Negeri Malang.

Wulandari. 2014. Prestasi Belajar Matematika Siswa Ditinjau dari Kecerdasan Intelektual, Kecerdasan Emosional, Kecerdasan Spiritual, dan Kecerdasan Sosial. Kresna Bina Insan Prima.

Viva. 2017. Kasus Bullying Anak Meningkat. Diakses melalui www.viva.co.id.

Metro. 2018. Diakses melalui metro tempo. Update: https://metro.tempo.co > Metro). 